\title{
DEPENDENCE OF MECHANICAL PROPERTIES ON POROSITY OF ALSI7MGO.3 ALLOY DURING GRAVITY CASTING
}

\author{
Iryna Hren, Stefan Michna, Lenka Michnova \\ J. E. Purkyne University in Usti nad Labem, Czech Republic \\ iryna.hren@ujep.cz, stefan.michna@ujep.cz, lenka.michnova@ujep.cz
}

\begin{abstract}
In cast material, due to the technology and process used, the presence of defects in the cast material structure, such as porosity, inclusions and oxidative membranes, is inevitable. All these discrepancies have a negative effect on the resulting mechanical value of the cast material. Several works have shown that especially porosity in particular negatively degrades the fatigue properties, strength and ductility of the material. Since most fatigue failures begin at the surface of the material, surface roughness becomes an extremely important factor in determining the fatigue strength of the cast parts, and structural defects (porosity, inclusions, oxide membranes) near the surface have a decisive influence on the initiation of material breakage. The work is focused on the fractographic analysis of the fracture surface of AlSi7Mg0.3 casting alloy. Using the electron scanning microscope, the fracture area of the samples was analysed. Optical metallography identified structural components of castings just below the fracture surface as well as the course of the fracture line. An increased number of oxygen, carbon, chlorine and fluorine elements occurred on the surface of the samples. The occurrence of these elements most likely results in material breakage, which also confirms the results achieved by the static tensile test. On the basis of the obtained results from the performed analyses, mechanisms of breaking of alloyed material of Al-Si type alloys were determined.
\end{abstract}

Keywords: fractographic analysis, $\mathrm{AlSi} 7 \mathrm{Mg} 0.3$ alloy, casting defects, mechanical properties, porosity.

\section{Introduction}

Nowadays, aluminium alloys are widely used in mechanical engineering and mainly in aviation and automotive due to their low density, mechanical properties, corrosion resistance, processability and recyclability. As a result of melting and casting, aluminium reacts with oxygen (formation of oxides and oxides membranes) and absorbs hydrogen as a result of decomposition of $\mathrm{H}_{2} \mathrm{O}$ molecules, which causes gasification [1]. Its main source is atomic hydrogen, which is formed during dissociation of water vapour adsorbed from the air, the wood in the batch, coating of salts, modification products, fuel, etc. The porosity of gas significantly disrupts the mechanical and fatigue properties of aluminium and its alloys [2-4] and reduces the life of Al-Si alloy parts. Therefore, it is very important to minimize the number of gaseous pores and their size in production of aluminium castings. The occurrence of porosity in aluminium castings is explained by the significant change in hydrogen solubility during transition of aluminium from liquid to solid state. Therefore, hydrogen in aluminium alloys has always been considered a major pollutant, and a large number of works was dedicated to methods of removing hydrogen from aluminium melts [5;6]. The porosity of the material significantly affects the mechanical properties (strength, ductility, fatigue) of the cast aluminium alloys as reported in the literature $[7 ; 8]$. The total casting porosity is the sum of the interdendritic porosities and hydrogen gasification.

\section{Experiment}

The presented experiment is part of a larger research focused on the study of the structure and phase transformations in the melt during casting of Al-Si alloys. AlSi7Mg0.3 alloy containing 92.7\% aluminium, $7 \% \mathrm{Si}$ and $0.3 \% \mathrm{Mg}$ was produced for the experiment. Melting was carried out at 750$760{ }^{\circ} \mathrm{C}$ and the gravity casting technology into a preheated metal mold (at $200{ }^{\circ} \mathrm{C}$ ) casts the samples and then leaves them in a metal form until cooled.

The resulting castings were cylindrical in shape with a diameter of about $19 \mathrm{~mm}$ and a length of $210 \mathrm{~mm}$ and became the basis for subsequent analysis of the microstructure. Spectral chemical analysis of the casting was performed on an optical emission spectrometer Q4 TASMAN, which is intended for analysis of virtually all metallic materials. In the casting, 5 measurements were carried out at the locations around the quarry, from which the average value of the individual elements was determined in Table 2. For all elements the chemical composition corresponds to the required composition of the AlSi7Mg0.3 alloy listed in Table 1. 
Chemical composition of casting, wt. \%

Table 1

\begin{tabular}{|c|c|}
\hline $\mathbf{S i}$ & 7.32 \\
\hline $\mathbf{F e}$ & 0.2 \\
\hline $\mathbf{C u}$ & 0.05 \\
\hline $\mathbf{M n}$ & 0.1 \\
\hline $\mathbf{M g}$ & 0.4 \\
\hline $\mathbf{A l}$ & resude \\
\hline
\end{tabular}

\section{Structure microscopy}

Four representative samples with different porosity were selected from individual castings based on the presence of macro porosity. The sample labelled A1 showed the highest porosity, while the sample A4 showed the lowest porosity. Metallographic samples used for quantitative porosity measurements and samples used for mechanical testing were prepared from A1-A4 samples. Five pore size measurements were made for each A1-A4 sample. Porosity was measured in various regions using the Olympus LEXT OLS 3100 laser optical microscope and image analysis methods (measured percent area of the image).

\section{Porosity of sample A1}

Sample P1 showed the highest material porosity of all samples. In some areas of the sample A1, larger pores seen by a naked eye appeared. The areas with the largest pores are shown in Figure 1 (porosity $3.822 \%$ area of the image).

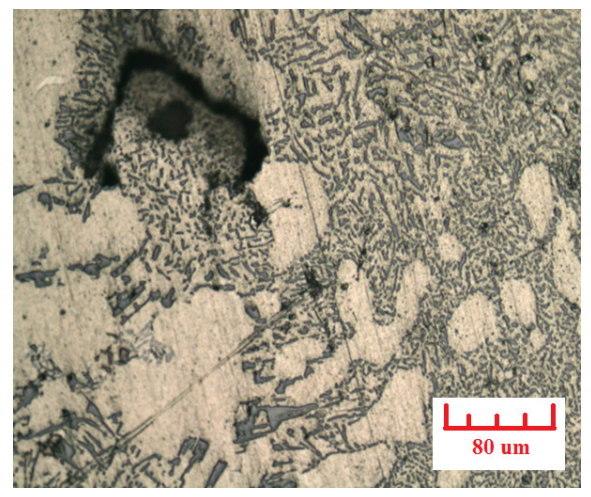

Fig. 1. Microstructure with porosity of sample A1, magnification 200x

Table 2

Measurement of porosity of sample A1 cast from AlSi7Mg0.3 alloy

\begin{tabular}{|c|c|c|c|}
\hline Sample & Measurement & $\begin{array}{c}\text { Value, \% of image } \\
\text { area }\end{array}$ & $\begin{array}{c}\text { Average value, \% of } \\
\text { image area }\end{array}$ \\
\hline \multirow{4}{*}{ A1 } & 1 & 1.735 & \multirow{2}{*}{} \\
\cline { 2 - 3 } & 2 & 2.104 & \multirow{2}{*}{2.801} \\
\cline { 2 - 3 } & 3 & 3.822 & \multirow{2}{*}{} \\
\cline { 2 - 3 } & 4 & 2.353 & \\
\cline { 2 - 3 } & 5 & 1.192 & \\
\hline
\end{tabular}

Table 2 shows the measured porosity values of the sample A1, which was prepared from the most porous portion of the AlSi7Mg0.3 alloy (average porosity $2.801 \%$ of the image area).

\section{Porosity of sample A2}

The microstructure of the sample A2 with measured porosity (porosity $1.573 \%$ of image area) is shown in Figure 2. Compared to microstructural images of the sample P1, the difference in size and shape of dendritic cells and excluded intermetallic phases. The size of dendritic cells is in tens of micrometers and their shape is elongated (in the direction of intense heat dissipation from the alloy). The measured porosity values of the sample A2 are shown in Table 3 (average porosity is $1.406 \%$ of the image area). 


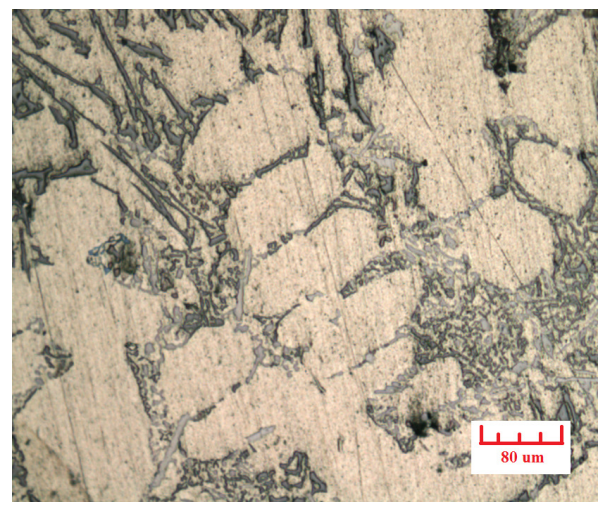

Fig. 2. Microstructure of sample A2 with enhanced porosity, used for quantitative measurement by image analysis methods, magnification 200x

Table 3

Measurement of porosity of sample A2 cast from AlSi7Mg0.3 alloy

\begin{tabular}{|c|c|c|c|}
\hline \multirow{2}{*}{ Sample } & Measurement & $\begin{array}{c}\text { Value, \% of image } \\
\text { area }\end{array}$ & $\begin{array}{c}\text { Average value, \% } \\
\text { of image area }\end{array}$ \\
\hline \multirow{4}{*}{ A2 } & 1 & 0.653 & \multirow{3}{*}{} \\
\cline { 2 - 3 } & 2 & 1.222 & \multirow{2}{*}{1.406} \\
\cline { 2 - 3 } & 3 & 1.573 & \multirow{2}{*}{} \\
\cline { 2 - 3 } & 4 & 1.331 & \multicolumn{1}{|c}{} \\
\cline { 2 - 3 } & 5 & 0.848 & \multicolumn{2}{|c}{} \\
\hline
\end{tabular}

\section{Porosity of sample A3}

Figure 3 shows the microstructure of the sample and the porosity used for image analysis ( $1.088 \%$ of the image area). The measured porosity values of P3 are shown in Table 4 (average porosity is $0.798 \%$ of the image area). As for the sample A2, we can see seemingly oriented dendritic cells on the A3 sample microstructure. The primary dendrite axis is significantly extended along one axis due to the intense heat dissipation from the casting in one direction. The size of dendritic cells and intermetallic phases is significantly smaller compared to the sample A1.

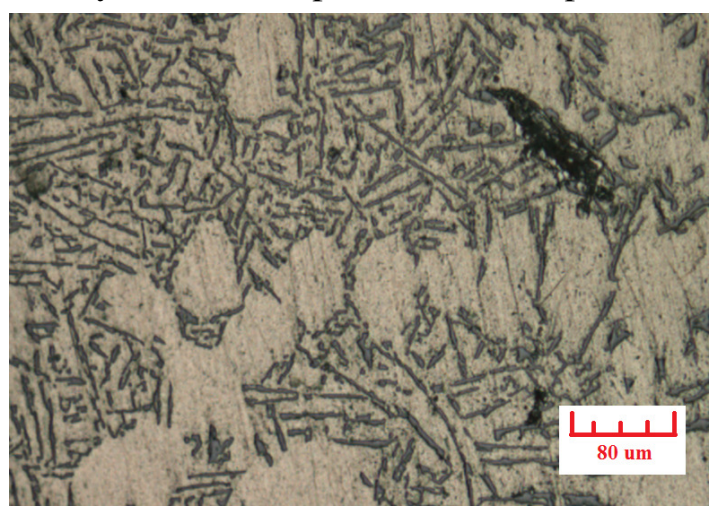

Fig. 3. Microstructure with porosity of sample A3, magnification 200x

Table 4

Measurement of porosity of sample A3 cast from AlSi7Mg0.3 alloy

\begin{tabular}{|c|c|c|c|}
\hline Sample & Measurement & $\begin{array}{c}\text { Value, \% of image } \\
\text { area }\end{array}$ & $\begin{array}{c}\text { Average value, \% } \\
\text { of image area }\end{array}$ \\
\hline \multirow{4}{*}{ A3 } & 1 & 0.192 & \multirow{2}{*}{0} \\
\cline { 2 - 3 } & 2 & 0.852 & \multirow{2}{*}{0.798} \\
\cline { 2 - 3 } & 3 & 1.088 & \multirow{2}{*}{} \\
\cline { 2 - 3 } & 4 & 0.856 & 1.003 \\
\hline
\end{tabular}




\section{Fractographic analysis of microstructure}

In Figure 4, predominantly dendritic failure of the test rod with a noticeable revealed interdendritic porosity on the fracture surface can be seen. Looking at the fracture surface, areas characterized by the structural failure with a hole morphology with a local smooth decoupling of the material due to the occurrence of an oxide membrane on the fracture surface can be distinguished. The spectrum of the analysed elements of the surface EDS analysis confirms these areas by the presence of $\mathrm{O}(10.93$ wt. \%) and C (17.65 wt. \%), where from the standpoint of stoichiometric ratio it can be deduced that it is the presence of an oxide membrane at the breach boundary, which caused a total breach and crack propagation across the entire casting cross section.

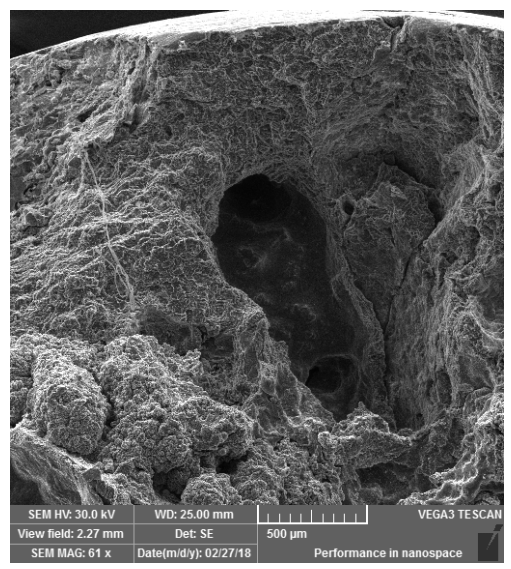

Fig. 4. SEM analysis - ductile intercrystalline fracture

The area analysed in Figure 5 shows predominantly interdendritic failure of the test rod. In a detailed view of the fracture surface, it is possible to distinguish areas with the appearance of light spherical particles (oxides) and to observe the exposed dendritic cells due to increased local interdendritic porosity. Surface EDS analysis on the fracture surface identified the presence of O (16.5 wt. \%), C (18.41 wt. \%) and F (2.57 wt. \%), where it can be deduced from the stoichiometric ratio that they are oxides and residues of refining salts. The amount of undesirable elements was manifested in large quantities, resulting in formation and spread of the fracture. On the analysed surface from the bottom of the casting a spherical rounding of O-containing particles was documented on the fracture surface, which also caused the test rod to break.

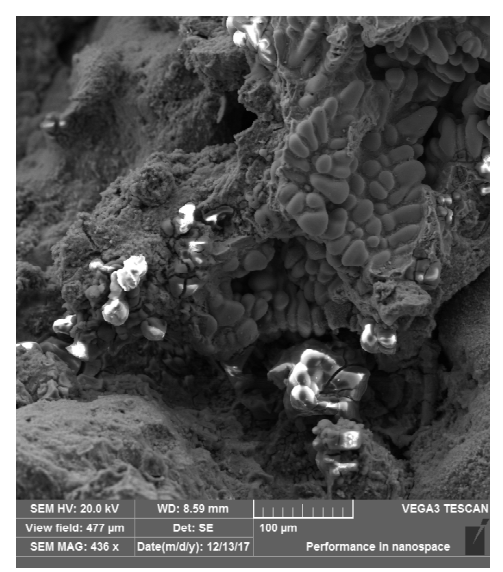

Fig. 5. SEM analysis - bright spherical particles - oxides and exposed dendrites on fracture surface

In Figure 6 exposed dendritic cells and interdendritic porosity can be observed. Surface EDS analysis of the bright areas of fission failure on the fracture surface shows the presence of $\mathrm{O}$ (5.99 wt. \%) and C (24.24 wt. \%), where it can be deduced from the stoichiometric ratio that it is the presence of an oxide membrane on the surface of a smooth flat plate, causing total casting failure. 


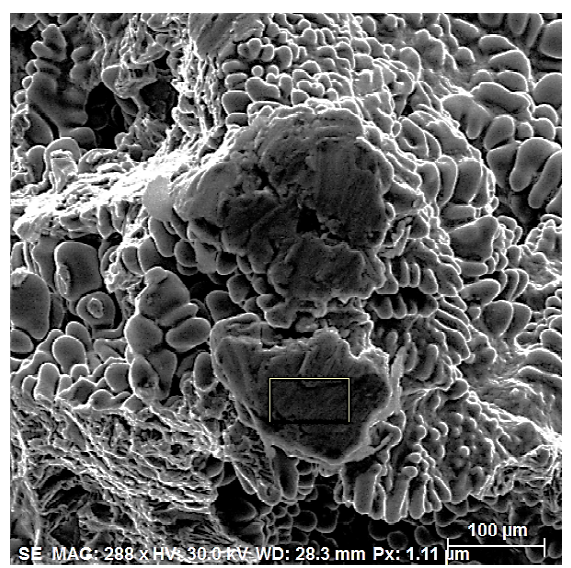

Fig. 6. SEM analysis - exposed dendrites on fracture surface

\section{Static tensile test}

In the second part of the experiment, $\mathrm{AlSi} 7 \mathrm{Mg} 0.3$ castings were cast and then samples (according to ČSN EN ISO 4287) were tested by tensile testing.

The relationship between the tensile strength and porosity is shown in Figure 7. The x-axis shows the measured porosity values (by microscopic analysis) from the \% area of the image. The y-axis shows the tensile strength values. The related porosity and strength limits correspond to the samples prepared from the same part of the studied casting (samples A1 - A4). There is a strong dependence of the load capacity and the size of the porosity in the figures. An increase in the porosity of $0.646 \%$ to $1.4-2.8 \%$ leads to a decrease in the tensile strength by $20-30 \%$.

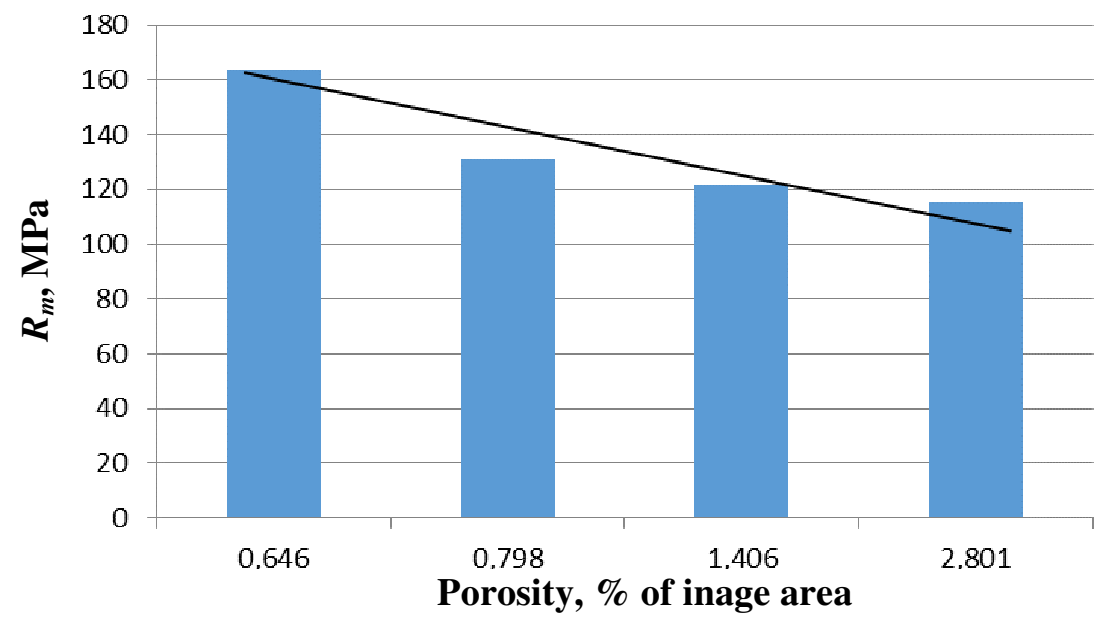

Fig. 7. Dependence of tensile strength on porosity, AlSi7Mg0.3 alloys

\section{Conclusions}

Quantitative porosity measurements were performed using the image analysis as the percentage of porosity from the total image area for samples prepared from AlSi7Mg0.3 alloy. Five measurements were made for each sample and were performed in different regions and the mean value was calculated. The measured porosity range is wide, starting at $0.331 \%$ and reaching up to $3.822 \%$.

Looking at the fracture surface in detail, areas with large areas of oxide membranes can be distinguished, causing smooth deco-separation of the material and the remainder of the fracture being characterized by intercrystalline failure with the presence of exposed dendrites with a well morphology. EDS analysis of the light area of ductile intercrystalline fracture shows the presence of $\mathrm{O}$ and $\mathrm{C}$ in large quantities, confirming the presence of oxide membranes that initiated crack breakage and material propagation. It has been found that refinery salt residues remain in the test specimens and oxide membranes occur. Thanks to this finding, we can conclude that there was insufficient refining and degassing of the melt before casting. In the microstructure, spherical oxygen-containing particles 
are present on the fracture surface of the cast. These spherical oxide particles also affect the propagation of fracture in the material. From all performed analyses and fractographic analysis it can be concluded that the initiator of crack penetration and subsequent cracking of the casting under load is the large amount of oxide membranes and oxides, which caused total failure and crack propagation across the casting cross section.

The static tensile test showed a relationship between interdendritic porosity in the material structure and its mechanical properties. Reducing the tensile strength by $20-30 \%$ can be seen for increased porosity, ranging from $0.646 \%$ to $1.4-2.8 \%$. It can be concluded that the effect of porosity on the mechanical properties is insignificant when the porosity is below $0.5 \%$ of the total area.

\section{Acknowledgements}

This contribution was created within the support of the project SGS $48207152022-4801$ at UJEP.

\section{References}

[1] Michna, Š. a kol. Encyklopedie hliníku. 1. Vydání, Prešov, SR: Adin s. r. o., 2005. 700 p.

[2] Bolibruchová,D., Tillová, E. Zlievarenské zliatiny Al-Si. Žilina: EDIS - vydavatel’stvo ŽU, 2005. $180 \mathrm{p}$.

[3] Mondolfo L. F. Aluminium Alloys, Structure and Properties. Butterworths, London, 1979. 986 p.

[4] Hren I., Svobodova J., Michnova L., Michna Š., Beneš L. Research on the effect of beryllium on the modification and change of mechanical properties of al-si alloys. Advanced manufacturing and repair technologies in vehicle industry monograph, 2018, pp. 123-136.

[5] Tillova, E., Chalupova, M., Hurtalova, L., Durinikova, E. Quality Control of Microstructure in Recycled Al-Si Cast Alloys. Manufacturing Technology, vol. 11, No. 11, 2011, pp. 70-76.

[6] Náprstková, N., Cais, J., Svobodová, J. The Effect of Modification by Strontium of the AlSi7Mg0.3 Alloy on the Surface Roughness. Manufacturing Technology, Vol. 13, No. 3, 2013, pp. 380-384.

[7] Michna, Š., Lukáč, I. Praktická fraktografie. Univerzita J. E. Purkyně v Ústí nad Labem, OPTYS, spol. s r. o., 2012. 237 p.

[8] Hren, I., Michna, Š., Cais, J., Lysońková, I., Hodinař, L.: Výzkum vlivu beryllia na modifikaci a změnu mechanických vlastností u slitiny ASi7Mg0,3. Strojírenská Technologie, XXIII, No. 1, 2018, pp. 12-17. 